13. Müller.-Ueber Ruptur der Corneo-Skleralkapsel durch stumpfe Verletzung. Franz Deuticke, Leipzig und Wien, 1895.

14. Schaefer.-Pathol. Anat. Befund einer atypischen indirekten äquatorialen Skleralruptur durch Kuhhornstosz. Arch. f. Ophthal., Vol. CXVII, pp. 693-701, 1926.

15. von Szily.-Atlas der Kriegsaugenheilkunde, 3e Lieferung. Ferd. Enke, Stuttgart, 1918.

16. Tillema, A.-Anatomie en kliniek van traumatisch glaucoom. Diss., Amsterdam, 1935.

17. Partial rupture of the lamina cribrosa from contusion of the globe. Arch. of Ophthal., Vol. XV, 1936.

18. Wagenmann.-Die Verletzungen des Auges. Handb. d. g. Augenheilk. (Graefe-Saemisch), 3e Aufl., 1915.

19. Wintersteiner.-Beiträge zur pathol. Anat. d. traumatischen Aniridie etc. Arch. f. Ophthal., Vol. XL, ii, pp. 30-43, 1894.

\title{
VASCULARISATION OF IRIS AND CORNEA IN DIABETES
}

BY

\section{DR. R. D. LAWRENCE and A. HaRold LeVy}

VASCULAR eye changes are frequent in diabetes, especially in elderly, long-standing cases, and are usually confined to the posterior segment of the eye, especially the retina. Much less frequently are found oedema of the posterior layer of the iris with ectopia uveae and occasional vascularisation of the iris, a condition of affairs which makes the eye unusually prone to iridocyclitis and glaucoma.

Vascularisation of the iris and cornea, such as we record, must be extremely rare and is not mentioned in the previous literature.

\section{Diabetic History and Condition}

Diabetes was diagnosed in 1923 in a slightly obese man, aged 49 years, home on leave from India. He had had no previous illness of any importance and no family history of diabetes. The hyperglycaemia and glycosuria were easily controlled by diet and no diabetic complications or organic abnormalities were present. There is no doubt that diet was not strictly followed and when next seen in 1926, heavy glycosuria, some ketonuria and a blood-sugar of 0.425 per cent. were found. Insulin was advised, but taken very irregularly and the patient was not seen again for eight years (May 1934). Fair general health had been maintained during that time although without doubt the diabetes had seldom been properly controlled. In 1933 the patient nearly died in India from a huge carbuncle, and in February 1934 from lobar pneumonia and empyema, when acute cystitis also developed. At this 
time he was given 50 units of insulin a day and sent to England as soon as he was fit to travel. Two weeks before arrival he noticed his first serious eye trouble, becoming quite suddenly nearly blind in his left eye.

Physical Condition: May-December 1934. On arrival the diabetes was quite uncontrolled as he had had no insulin for 2 days - this is typical of the patient's attitude. The urine contained 5 per cent. of sugar, moderate amounts of ketones and the blood-sugar was $\mathbf{0 . 4 2 0}$ per cent. Moderate albuminuria and slight chronic bacillus coli infection were present.

The diabetes was complicated by severe peripheral neuritisnumb and painful feet and absent knee and ankle jerks-but his general condition was fairly good. Heart and lungs were normal, no marked general arteriosclerosis, pulses in feet good, and blood pressure $142 / 83 \mathrm{~mm}$. The liver was slightly enlarged and smooth, not tender, but with a toughish rounded edge.

The details of the eye condition are described separately.

The diabetes was easily controlled by 40 units of insulin a day, with a diet of 130 grams carbohydrate: glycosuria and ketosis were absent, and the blood-sugar varied in the day from 0.1 to 0.200 per cent., being mostly at the lower level.

The general health and neuritis quickly improved and the patient was soon able to walk normally. In spite of this, the eye condition steadily deteriorated.

The following blood tests in October 1934 showed no particular abnormalities.

\begin{tabular}{lllc} 
& & \multicolumn{2}{c}{ Whole blood } \\
Blood-urea ... & $\ldots$ & $\ldots$ & 49 mgm. per 100 c.c. \\
Cholesterol ... & $\ldots$ & $\ldots$ & 219 mgm. per 100 c.c. \\
& & & Serum \\
Total Protein & $\ldots$ & $\ldots$ & 7.0 per cent. \\
Albumen ... & $\ldots$ & $\ldots$ & $4^{\circ} 9$ per cent. \\
Globulin (by difference) & $\ldots$ & 2.1 per cent. \\
A/G ratio ... & $\ldots$ & $\ldots$ & $2^{\circ} 4$ per cent. \\
Fat (Ruckert) & $\ldots$ & $\ldots$ & $0^{\circ} 68$ c.c. per cent. \\
Calcium ... & $\ldots$ & $\ldots$ & $10^{\circ} 2$ mgm. per 100 c.c.
\end{tabular}

\section{Ocular Condition}

First seen about eyes on May 16, 1934, when the vision in the right eye was $6 / 9$ partly and in the left counting fingers at half a metre.

Ophthalmoscopically: Right.--Veins much dilated, with local narrowings-few spots of yellowish exudate about the macular area and a few fine haemorrhages. 
Left.-Gross haemorrhages all around disc and macula, but periphery fairly clear.

One week later the left eye became painful-the pupil was semidilated and the tension was raised. From the fundus there was only a dull red reflex and details could not be made out.

By the end of June, 1934, the tension in the left eye had increased. There was an hyphaema and fresh vessels were seen in

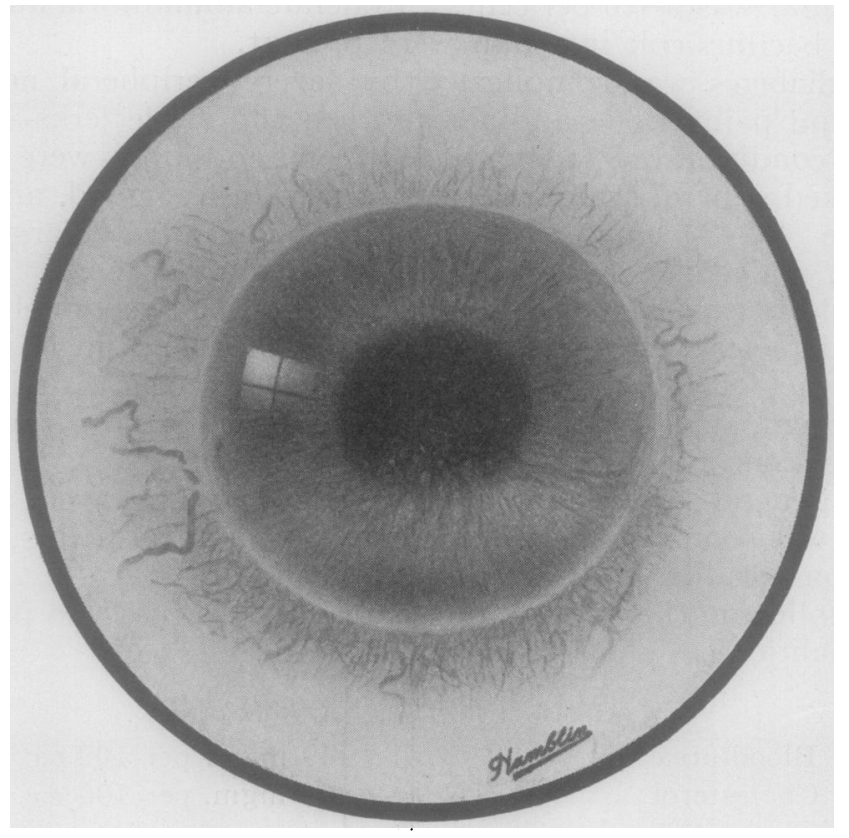

the posterior layers of the cornea and on the iris. The drawing shows the condition at that time.

By the early part of August, 1934, that is about seven weeks after their first appearance, the vessels on the cornea had disappeared. A small hyphaema remained-the iris was discoloured with many vessels on its surface. Dull red fundus reflex and bare perception of light.

By the end of August, 1934, this left eye became totally blindwith fixed oval pupil and many vessels on iris-fundus details could not be seen. The tension remained full, but not as high as it had been in June, there was very little pain now and when last seen in February, 1935, had remained the same.

The right eye remained more or less as it was when first seen until the end of August, 1934. The haemorrhages had become more numerous, but without much interference with vision. 
On August 28, 1934, there came suddenly extensive haemorrhages in the central portion of the retina and many peripheral haemorrhages, and vision sank to counting fingers at 2 metres.

In this right eye the haemorrhages were confined to the posterior segment, but glaucoma became a dominating feature and on the suggestion of $\mathrm{Mr}$. Whittington a paracentesis was performed on November 6, 1934. This relieved the pain for a time, but the tension gradually increased again and the eye became totally blind.

He was last seen on February 22, 1935, just before his departure for India and then he was having transitory attacks, at infrequent intervals, of pain in both eyes, but was completely blind.

The peculiar feature of this case is the development of vessels on both surfaces of the cornea and in a sense more remarkable still, their complete regression. No record of a similar happening has been found and it seemed worth while to record this.

\section{TRACHOMA :}

An investigation into the question of the presence of Bacterium granulosis (Noguchi) in Cases of Trachoma in Glasgow

BY

S. Spence Meighan, B.Sc., M.B., Ch.B., F.R.F.P.S.G. SURGEON, GLASGOW EYE INFIRMARY. OPHTHALMIC SURGEON, STOBHILL HOSPITAL, GLASGOW

AN D

Mary Urquhart, M.B., Ch.B.

BACTERIOLOGIST, STOBHILL HOSPITAL, CORPORATION OF GLASGOW

Hideyo NoguchI working at cases of trachoma among the American Indians at a reservation in New Mexico isolated a hitherto undescribed bacillus to which he gave the name Bacterium granulosis. Papers giving the result of this work were published in 1928, (The Etiology of Trachoma, Hideyo Noguchi, Jl. Exper. Med., XI,VIII, Supplement No. 2).

Since that time a mass of literature has appeared concerning the presence and aetiological significance of this micro-organism. A point which emerges is that different investigations show much diversity regarding the presence of the bacterium in cases of undoubted trachoma.

In view of this we set ourselves to answer the question whether or not B. granulosis, (Noguchi), was present in cases of trachoma occurring in Glasgow. The material investigated was obtained 